\title{
Income Smoothing and CEO Job Security
}

\author{
*Lanouar Charfeddine ${ }^{1}$, Wided Bouaine ${ }^{2}$ \\ ${ }^{1}$ College of Administrative Sciences, Najran University, KSA \\ ${ }^{2}$ Higher institute of Accounting and Firm Administration of Tunis, University of Manouba, Tunisia \\ *lanouar_charf@yahoo.fr
}

\begin{abstract}
The purpose of this paper is to examine the link between income smoothing and CEO tenure on a sample of 271 U.S companies over the period 1993 to 2003. Moreover, in order to test the extent of income smoothing for job security and specifically for a lengthen tenure; we also have considered some CEOs characteristics such as age and tenure. Empirical results of Wilcoxon statistics and discriminating analysis show that when the current (future) performance is good, the CEOs find the sufficient margins to manage the earnings to leave in reserve for the future performance (or borrow for the current performance). In addition, the results of the multivariate model show that the CEO smooth the income by decreasing accruals, so they shift current earnings to future periods when current earnings is high and future earnings is low to lengthen their tenure.
\end{abstract}

Keyword: Income smoothing, current performance, future performance, tenure, job security

\section{Introduction}

In the last three decades, earning management has been the subject of considerable researches in the accounting literature. One of the most important questions that have attracted a lot of interest in earning management concerns the relationship between job security and income smoothing. Nowadays, there are some consensus between researchers that CEOs' smooth income in order to maximize their expected length of tenure, see Fudenberg and Tirole (1995), DeFond and Park (1997), Boyer and Molina (2006), and Ahmed, Lobo and Zhoo (2001). Empirical evidence show that CEOs' use the flexibility allowed in the generally accepted accounting procedures or using IFRS to smooth income, see for example, Gaver et al. (1995), and DeFond and Park (1997). Fudenberg and Tirole (1995) suggest that executives engage in earning smoothing because of concerns about conserving their positions or avoiding dismissal. DeFond and Park (1997) find that CEO of firms having poor (good) performance in the current period and expected good (poor) performance in the next period choose income-increasing (income-decreasing) discretionary accruals in order to reduce the threat of dismissal. Ahmed et al. (2001) find evidence for the hypothesis following that income smoothing is greater when managers' job security concerns are more severe. The authors use some firm characteristics supposed to imply greater job security concerns for managers.

Recently, Zhang (2009) deduces that at the starting of their tenures and for building reputation of ability the CEOs are incited to inflate earnings. Moreover, Zhang (2009) show also after establishing their good reputations through their long tenures; the COE's behave less aggressively in order to protect their reputations. Hazarika et al. (2011) show that a CEO's tenure is negatively related to how earnings are managed during his term in office. They find that earnings management decreases after a CEO forced departure. They show also that the relation between earnings management and forced turnover occurs both in firms with good and bad performance, this paper contributes to the empirical literature in this field by examining the link between job security and income smoothing. Specially, we investigate whether there is a significant link between tenure and income smoothing. To do that, we follow the same line as DeFond and Park (1997) in measuring pre-amenaged earning. Our study differs from the Defond and Park (1997) work on the manner of testing the relation between the income smoothing and job security. Moreover, in contrast to Ahmed et al. (2001)1, in a work we have introduced some social variables such as age (1), age (2) and tenure. Indeed, Weishbach (1988), Murphy and Zimmerman (1993), and Paquerot (1996) found a significant relation between the CEO turnover and their age. To do that, we have

\footnotetext{
${ }^{1}$ Ahmed et al. (2001) examine the relation between income smoothing and three proxies for job security: competition, product durability and revenue volatility.
} 
introduced the variable, age (1), for seeking, if the CEO age have a significant impact on tenure by stimulating income smoothing. In the other hand, Goyal and Parck (2001) suggest that around the age of 65 years the majority of the departures are voluntary. Thus, we introduced this variable, age (2), to assess whether the CEOs persists in their office around retirement age. The results of Goyal and Parck (2001) show that a long tenure is associated with a CEO age close to the retirement age. Alternately, a CEO with long tenure can build a base of power.

Empirical results indicate that discretionary accruals can discriminate between the firms experiencing good current (future) performance and firms experiencing bad current (future) performance. Furthermore, the results of the discrimination analysis show that job security variables are not significant. This result must be carefully taken, because the average of the tenure in both groups' good current (future) performance and bad current (future) performance is almost the same, which approaches 10 years. Our multivariate analysis proves also that CEOs engage in earnings decreasing accruals in order to lengthen their tenure, and thus by shifting current earnings to future periods when current earnings is high and future earnings is low. This result confirms our hypotheses and aligns them with the intuition of Fudenberg and Tirole (1995). The remainder of the paper is organized as follows. Section 2 reviews empirical literature and develops our hypotheses. Section 3 explains the research design and describes the sample selection criteria. Section 4 presents the empirical results. Finally, Section 5 summarizes and concludes the paper.

\section{Literature Review and Hypotheses}

The CEO's career concerns: Fama (1980) suggests that explicit incentive contracts do not motivate CEOs since a CEO can be disciplined through career concern based implicit incentives. His arguments that the careers concerns reduce agency problems between the CEOs and the shareholders. Gibbons and Murphy (1990) affirm that the careers concerns are more important when the CEOs are farther the retirement age. They documented that older CEOs' cash compensation is more sensitive to their firms' performance, consistent with older executives being more motivated by explicit rather than career concern around retirement age. However, Brickley et al. (1999) argue that careers concerns do not take end at the retirement age. Indeed many CEOs serve on their own or other boards after retirement (Lee, 2007; Song and Thakor, 2006). They notice that the retired CEOs became more common on boards. Empirical evidence indicates that the careers concerns decrease when CEOs use the flexibility afforded under current GAAP to manipulate earning, as well as prolonging their tenure (Dechow and Sloan, 1991; Murphy and Zimmerman, 1993; Koch and Wall, 2000) or affecting the decisions of investment (Song and Thakor 2006).

The CEO's opportunism and the earning management: Lambert (1984) suggests that optimal contracting with risk adverse managers can generate smoothing which is considered as one earning management scheme. He describes smoothing in a two-period moral hazard setting where the optimal contract has second-period managerial compensation increasing in first-period output. Thus, when firstperiod performance is good, the marginal utility of consumption in the second period is low for the manager, and he reduces effort. Healy and Wahlen (1998) attribute the opportunistic character to the earning management. This approach was tested by several empirical studies. Godfrey, Mather and Ramsay (2001) argue that new CEOs have incentives both to manage earnings and to engage in impression management by manipulating the impressions created by graphs in financial reports. In the year of CEO change, they find evidence of downward earnings management but no evidence of any unfavorable impression management of the key financial variables graphed. As posited, they find evidence of upward earnings management and favorable impression management in the year after a CEO change. These results are strongest for the sub-sample where the CEO change was due to a resignation rather than a retirement. This result confirms that the new CEOs are opportunistic making a big bath, which is in line with the results of Murphy and Zimmerman (1993).

Chen and Cheng (2002) find that the abnormal accrual-based anomaly is correlated with CEOs incitements to record abnormal accruals. Future returns are negatively associated with abnormal accruals recorded for opportunistic earnings management purposes. These results suggest that investors' failure to distinguish CEO's incitements to record abnormal accruals provides an explanation for the abnormal accrual-based anomaly. This failure lets CEOs engaging in opportunistic earnings management, and thus hinders CEO's ability to communicate private information to the stock market via abnormal accruals. The authors conclude that for opportunistic earnings management purposes, CEOs record 
abnormal accruals, such as hiding poor performance or postponing the recognition of good performance, in order to maximize their utility with no intention to disclose private information. CEOs have incentives to hide poor performance because their wealth, reputation, and job security are positively affected by earnings (Fudenberg and Tirole 1995; Weishbach 1988). Ahmed, Lobo and Zhoo (2001) show that when current performance is good and future performance is expected to be bad, CEOs of firms operating in competitive industries, in durable goods industries, and in more uncertain operating environments engage significantly more negative discretionary accruals consistent with greater magnitude of income smoothing. Furthermore, they note that when current performance is low and future performance is expected to be high, CEOs of firms operating in durable goods industries and in more uncertain operating environments engage significantly more positive discretionary accruals consistent with a greater magnitude of income smoothing. Demers and Wang (2010) prove that younger CEOs engage less incomeincreasing accruals, by about $1 \%$ of total assets, than older CEOs. In addition, they find that younger managers engage less income increasing real activities.

Earning management and CEO departure: The US context is generally consistent with incoming CEOs 'taking a bath' (De-Angelo, 1988; Elliott and Shaw, 1988; Murphy and Zimmerman, 1993; Pourciau, 1993). De-Angelo (1988) detects that well CEOs manipulate earnings downwards in the year of the takeover and communicate higher earnings the following year. This is used to maintain their claims of being better CEOs. Elliott and Shaw (1988) find that 39\% of their sample had known CEO change in the period of the write-off. Their evidence confirms the affirmation that new CEOs seek to impute poor results to their predecessors. In an important study on managerial horizon problems, Dechow and Sloan (1991) certify that CEOs have opportunistic behavior, so they boost earnings during their final years in office by reducing R\&D expenditures. They concentrate on firms in R\&D-intensive industries and demonstrate that expenditure in R\&D are significantly lower in a CEO's terminating year and year of departure, showing that CEOs with short horizons accomplish value-decreasing decisions in order to enhance current earnings. Murphy and Zimmerman (1993) conclude that decreases in R\&D, advertising, capital expenditures, and accounting accruals are better explained by the bad performance of the firm than by leaving CEOs practicing discretion. They show that incoming CEOs take a big bath in the year of change.

Similarly, Demers and Wang (2010) declare that aged CEOs are associated with low discretionary expenditures in R\&D relative to their younger counterparts. They deduce that aged CEOs are more likely than younger CEOs to engage in real transaction manipulation. Pourciau (1993) separates between voluntary and forced CEO's turnover. She suggests that there are serious motivations and opportunities for earnings management in the case of forced turnover. From a sample of 73 CEO changes in the US, Pourciau (1993) proves empirical evidence consistent with her hypothesis that arriving CEOs manipulate accruals in a way that declines earnings in the year of change and enhances earnings in the following year. Further, her evidence shows that the arriving CEOs recorded large write-offs in the year of the change. Pourciau (1993) reveals that the evidence is also consistent with the previous managers' failure to make these write-offs when they were necessary. This may allow the new CEO to attribute poor performance to its predecessors, support claims of being better CEO, and establish a low base for executive compensation tied to reported earnings. Recently, Hazarika et al. (2011) find that earnings management and forced turnover occurs in both firms with good and bad performance, and when the accruals work to inflate or deflate reported earnings.

Hypotheses of study: This section begins with a brief summary of the Fudenberg and Tirole (1995) model. This model implies that managers, with greater job security concerns, will engage in income smoothing largely. Fudenberg and Tirole (1995) show that income smoothing to augment job security emerges in equilibrium if the following hypotheses are maintained. First, managers have non-monetary private benefits from supervising the firm. Second, the firm cannot deliver itself to a long-term motivation contract, so that bad performance may result in managers' dismissal, see for instance Murphy and Zimmerman (1993). Third, present earnings are more important than earlier earnings (information decay) in managers' running evaluation. Cumulatively, these hypotheses imply that managers will increase their earnings in poor performance and save for the future in good performance in order to prolong their tenure. The first two hypotheses indicate that managers have an incentive to boost current earnings by relocate future earnings to the current period to diminish the risk of dismissal in the short term. Furthermore, this incentive increases as the level of current performance decreases. These two hypotheses signify that managers will increase current income by borrowing from future periods when needed, but they do not suggest that managers must shift current income for future periods when needed, which is also demand for income smoothing. This is the objective of the third hypothesis that current 
earnings are more important than past earnings in managers' running judgment. In other words, good past performance will not compensate for bad current performance because of information decline. This implies that managers are less interested with dismissal in good period; rather, they are motivated to save for future bad period by altering current earnings to future times to extend their tenure. In this paper, we re-examine some hypothesis by considering 271 US companies. The first hypothesis to test is,

Hypothesis 1: The CEOs smooth earning according to current and future performance in order to lengthen their tenure. The CEOs may smooth earning by making income increasing or income decreasing. Therefore, to investigate these two cases, we subdivide our hypothesis on two other hypotheses.

Precisely, we investigate whether CEOs borrow future earnings for the current period to prolong their tenure. In that case, COEs' choose income increasing discretionary accruals when current performance is poor and future performance is good.

Hypothesis (a): If the current performance is poor and the future performance is good, CEOs will be motivated to decrease the future earnings to the detriment of the current one in a purpose to lengthen their tenure. The second emitted hypothesis predicts that the CEOs can shift current earnings for a possible use in the future. They choose income decreasing discretionary accruals, when current performance is good and future performance is poor.

Hypothesis (b): If the current performance is good and the future performance is poor, CEOs will be motivated to decrease the current earning by postponing them on the future period in order to lengthen their tenure.

\section{Methodology}

Data: The data sample is obtained from the list fortune 1000 and Forbes 200. We consider 271 companies over the period 1993 to 2003, a period supposed to be sufficient to study the links between earning smoothing and job security. The annual accounting data are manually collected from annual reports $10 \mathrm{~K}$. The job security data are taken from the circulars of information (proxy statement) which are due by virtue of the regulation 14a-3a of the American regulations on securities (the securities exchange act of 1934). The circulars of information are documents emitted to the shareholders, which contain information allowing them to make decisions informed during general assemblies. All the information concerning the job security (CEO' tenure, the type of departure and ages) was taken from the section of the appointment of the directors. We divide the sample into 12 subgroups based on their sector activities and where each subgroup must have at least 20 firms. A two digit classification of SIC was used to get the 12 subgroups, see for instance Defond and Park (1997). We note also that financial sector (SIC 6000 - 6999) and the regulated sector (4900 in 4999) was excluded based on their discretionary accruals that require a particular treatment. The following table gives the distribution of the sample by sector.

Table 1: Sector-based distribution of the firms of the sample

\begin{tabular}{lll}
\hline Sector & 2 digit SIC & Number Of firms \\
\hline Steel pipe and tube & 33 & 20 \\
Miscellaneous fabricated metal product & 34 & 23 \\
Electronic computer & 35 & 27 \\
Telephone and telegraph apparatus & 36 & 25 \\
Motor vehicle parts and accessories & 37 & 23 \\
Surgical and medical instruments and apparatus & 38 & 22 \\
Beverage & 20 & 23 \\
Greeting card & 27 & 21 \\
Industrial inorganic chemical & 28 & 23 \\
Wholesale electrical apparatus and equipment wiring supplies & 50 & 22 \\
Wholesale petroleum and petroleum product no bulk station & 51 & 20 \\
Pharmaceutical preparation & 73 & 22 \\
Total & & 271 \\
\hline
\end{tabular}

Variables: This subsection presents firstly the modified Jones model, as presented by Dechow et al. (1995) used to estimate the discretionary accruals, and secondly the approach used to evaluate the current and future performance, the measures of job security and control variables. 
Dependent variable (discretionary accruals): The discretionary accruals (DA) is estimated using the modified Jones model known to be the most used and efficient approach, see for example Dechow et al. (1995), Guay et al. (1996), and Ye (2007). The DA is measured as the residuals obtained by estimating the following regression using the least squared method,

$$
\frac{T A_{i t}}{A_{i t-1}}=\alpha_{1}\left[\frac{1}{A_{i t-1}}\right]+\alpha_{2}\left[\frac{\Delta R E V_{i t}-\Delta A R_{i t}}{A_{i t-1}}\right]+\alpha_{3}\left[\frac{P P E_{i t}}{A_{i t-1}}\right]+\varepsilon_{i t}
$$

Wheree $i$ indicates sample firm and $t$ the time.

$T A_{i t}$ is the total accruals.

$A_{i t-1}$ is the logarithm of the total assets.

$R E V_{i t}$ is the total annual revenues.

$A R_{i t}$ is the end of fiscal year accounts receivable.

$\triangle \mathrm{REV}_{\mathrm{it}}-\triangle \mathrm{AR}_{\mathrm{it}}$ is the change in cash-basis revenue.

$P P E_{i t}$ is the end of fiscal year gross property, plant, and equipment.

$\varepsilon_{i t}$ Are the residuals of the regression (1) considered as the measures of the earnings management obtained from the modified Jones model? The total accruals (TA) are computed, as in many others empirical works, see for example Jones (1991), Dechow et al. (1995) and Kothari et al. (2005) by using the following expression,

$T A_{i t}=\Delta C A_{i t}-\Delta C L_{i t}-\Delta \operatorname{Cash}_{i t}+\Delta S T D_{i t}-\operatorname{Dep}_{i t}$

Here as in the previous eq. (1), $i$ indicates sample firm and $t$ the time. The variables $\Delta \mathrm{CA}_{\mathrm{it}}, \Delta \mathrm{CL}_{\mathrm{it}}, \Delta \mathrm{Cash}_{\mathrm{it}}$, $\Delta \mathrm{STD}_{\mathrm{it}}, \mathrm{Dep}_{\mathrm{it}}$ are respectively change in current assets, change in current liabilities, change in cash and cash equivalents, change in debt included in current liabilities and depreciation and amortization expense.

Independents variables: All independents variables used in the following descriptive and multivariate approaches are summarized in Table 1 below.

Research Models: In order, to test the hypothesis H (a) and H (b) proposed in section 2, we use the following multivariate regression,

$$
\begin{aligned}
& \text { Disc. Accruals } s_{t}=\alpha_{0}+\alpha_{1} \text { Disc.Accruals } s_{t-1}+\alpha_{2} \text { Age1 }+\alpha_{3} \text { Age } 2+\alpha_{4} \text { Tenure }_{t}+\alpha_{5} \text { Liv }_{t} \\
& +\alpha_{6} \text { Size }_{t}+\alpha_{7} \text { Current.Perf } f_{t}+\alpha_{8} \text { Future.Perf } f_{t}+\alpha_{9}\left(\text { Current.Perf } f_{t}\right) *\left(\text { Future.Perf }_{t}\right)+\varepsilon_{i t}
\end{aligned}
$$

Where Disc. Accruals are the dependent variable estimated using the modified Jones (1995) model. The others variables are the independents variables defined and measured as in Table (2). The index $i$ designs the firms and $t$ the time. $\varepsilon_{i t}$ are the errors terms.

\section{Results}

Descriptive analysis: Descriptive statistics for all variables are given in Table 3. This table reports the mean, the standard deviation, the maximum, the minimum, the first quartile (Q1), the second quartile (Q2), and the third quartile (Q3). The discretionary accruals variable have a negative average (-0.299) with a standard deviation equal to 4.101. The second and third variables (current and future performance) behave similarly. Empirical results for the tenure and age 1 variables show that the average values are respectively equals to 9.456 and 56.428 years and their corresponding standard deviations are 8.090 and 9.041. For the Leverage and firm size variables, the empirical mean of the debts ratio on total assets is equal to 0.784 and the average of the logarithm of total assets is equal to 20.888 with a standard deviation equal to 1.885 . For the last variable, the age 2 which is a dummy variable, have an average of 0.428 and a standard deviation of 0.573 ? This later result shows that the average of CEO whom old around 63 to 65 is $42.8 \%$. 
Table 2: Variables Descriptions

\begin{tabular}{|c|c|c|}
\hline Variable & Symbole & Variable Masure \\
\hline $\begin{array}{l}\text { Financial Variables } \\
\text { Current } \\
\text { Performance }\end{array}$ & Current Perf & $\begin{array}{l}\text { To calculate the current performance of the company, } \\
\text { we use the following formula2: } \\
\text { current pre-amenaged profit - net current average } \\
\text { profit of the sample } \\
\text { current pre-amenaged profit= net current profits - } \\
\text { discretionary accruals }\end{array}$ \\
\hline $\begin{array}{l}\text { Future } \\
\text { Performance }\end{array}$ & Future Perf & $\begin{array}{l}\text { The future performance of the company, is calculated } \\
\text { as follow3: } \\
\text { Future pre-amenaged profit - net future average } \\
\text { profit of the sample } \\
\text { Future pre-amenaged profit= net future profits - } \\
\text { discretionary accruals }\end{array}$ \\
\hline Variable of job Security & & \\
\hline Age 1 & Age1 & number of years \\
\hline Age 2 & Age2 & $\begin{array}{l}\text { Takes the value } 1 \text { if the CEO is old around } 63 \text { to } 65 \\
\text { and } 0 \text { otherwise. }\end{array}$ \\
\hline $\begin{array}{l}\text { Tenure } \\
\text { Variable of control }\end{array}$ & Tenure & Number of years in CEO position. \\
\hline Firm size & Size & Log (total assets) \\
\hline Leverage & Lev & Total debts / total asset \\
\hline $\begin{array}{l}\text { Discretionary Accruals of } \\
\text { the previous year }\end{array}$ & Disc.Accruals $s_{t-1}$ & The value of the discretionary accruals at date $t-1$. \\
\hline
\end{tabular}

Table 3: Descriptive Statistics

\begin{tabular}{lllllllll}
\hline & N & Mean & $\begin{array}{l}\text { Std. } \\
\text { Dev }\end{array}$ & Min & Max & $\begin{array}{l}\text { 1th } \\
\text { Quartile }\end{array}$ & $\begin{array}{l}\text { 2th } \\
\text { Quartile }\end{array}$ & $\begin{array}{l}\text { 3th } \\
\text { Quartile }\end{array}$ \\
\hline Discretionary accruals & 2710 & -0.299 & 4.101 & -64.85 & 25.82 & -0.1087 & -0.028 & 0.036 \\
Current Performance & 2710 & 0.550 & 0.498 & 0.000 & 1.000 & 0.000 & 1.000 & 1.000 \\
Future performance & 2710 & 0.538 & 0.498 & 0.000 & 1.000 & 0.000 & 1.000 & 1.000 \\
Leverage & 2710 & 0.784 & 3.886 & 0.0027 & 135.860 & 0.341 & 0.471 & 135.860 \\
Firm size & 2710 & 20.888 & 1.885 & 13.567 & 27.42 & 19.799 & 21.140 & 22.026 \\
Tenure & 2710 & 9.456 & 8.090 & 1.000 & 52.000 & 3.000 & 6.000 & 12.000 \\
Age 1 & 2710 & 56.428 & 9.041 & 28.000 & 89.000 & 52.000 & 57.000 & 61.000 \\
Age 2 & 2710 & 0.428 & 0.573 & 0.000 & 1.000 & 0.000 & 0.000 & 1.000 \\
\hline
\end{tabular}

The behaviour of accruals according to the performance: We conduct the wilcoxon test and the Mann-Whitney U tests in order to compare on the one hand the results management between firms with current good performance and those with current poor performance. On the other hand, this test is also used to compare the discretionary accruals between firms with future good performance and that with future poor performance. Finally, we combine both types of performance to study the behaviour of accruals in purposes of job security.

2This difference was used by Defond and Parck (1997)

$3 \mathrm{We}$ shall use as substitute real future pre-amenaged profit seen the not availability of the past forecasts, especially that these last ones can be slanted because we work on past data (Defond and Parck on 1997). 
Wilcoxon test (see appendix Tables 4(a)-(b) and 5(a)-(b)): The wilcoxon statistics support the idea following that earning management is more intense in firms with current good (future good) performance than firms with current bad (future poor) performance. We deduct that when the current (future) performance is good. The CEOs find the sufficient margins to manage the earnings to leave in reserve for the future performance (or borrow for the current performance).

Current performance. Future performance and the smoothing earning: We study the behavior of discretionary accruals within nine groups according to the state of the current and future performance. The behavior of accruals is summarized in the following table.

Table 6: Discretionary accruals by current and future performance

\begin{tabular}{llll}
\hline Future performance & \multicolumn{2}{c}{ Current performance } \\
\hline \multirow{4}{*}{ Good } & Mean & Good & Poor \\
& Standard error & -0.927 & 0.104 \\
& Median & -0.687 & 0.308 \\
& N. Obs. & 984 & 0.03 \\
Poor & Mean & -0.177 & 474 \\
& Standard error & 0.397 & 0.187 \\
& Median & -0.077 & 1.05 \\
& N. Obs. & 505 & 0.048 \\
\hline
\end{tabular}

The First compartment in table 6 corresponds to the case where companies are characterized by a good current and future performance. For these companies, the CEOs do not run a risk of dismissal. The second compartment corresponds to companies of the sample that are characterized by a current poor performance and a future good performance. For this kind of companies. The result shows that the CEOs increase earnings for the current year in the detriment of the future years by increasing the discretionary accruals in order to avoid the threat of dismissal. This result is confirmed by the average value $(0.104)$ and the median value (0.03) of the discretionary accruals (positive). Indeed, from the 474 observations that form these companies there are 305 observations (65\% of current poor-future good performance) that have a positive mean. The third compartment of the sample corresponds to companies with current good and future poor performances. We remark, for these companies, that the CEOs decrease earnings for the current year in order to increase the benefit for the future years by decreasing the discretionary accruals to avoid the threat of the dismissal. This result is in line with the negatives values of the mean and median, respectively equal to -0.177 and -0.077 . The number (rate) of companies with negative mean and median is equal to 468 from the 505 that constitute the third subsample (92\%). The last compartment corresponds to companies with weak current and future performances. The CEOs of these companies have no margin to smooth the earnings. However, the positive and negative proportions of the discretionary accruals are comparable to the proportions founded in compartments 2 and 3 . Nevertheless, these results are not in line with the intuition of Fudenberg and Tirole (1995).

\section{The ventilation of the earning management and the job security according to the performance}

Case of companies with current good performance and with current poor performance: In this subsection, we are interested by the behaviour of the earning management and the job security according to current good performance and current bad performance cases. To do that, we have the discriminating function. The result of this estimation is reported in Table 7 below. Based on the result reported in table 7 panel A, we have conducted a statistic test for equality in means between each variable for the two groups. The result of this t-stat test is reported in the last column of table 7 panel B. Only for the two variables discretionary accruals and firm size, the null hypothesis of equality in means is rejected. In addition to this descriptive statistics analysis, we use also the linear discriminating function (LDF) approach in order to check which variables can be used to discriminate between the two groups of poor and good performance. The results of the estimated coefficients of the discriminating function and their corresponding F-statistics are reported in columns 2-4 of Panel B. These results confirm those of descriptive statistics, see panel A and last column of panel B. results show that only the discretionary accruals and firm size variables have a significant power to discriminate between both groups. This joins the Wilcoxon test results. The discrimination analysis shows that job security variables are not significant. 
Table 7: Discriminating analysis results according current performance

\begin{tabular}{|c|c|c|c|c|}
\hline $\begin{array}{l}\text { Panel A } \\
\text { State of the performal }\end{array}$ & & Me & & Std. dev. \\
\hline Poor & Discretionary accruals & 0.1 & & 0.844 \\
\hline & Leverage & 0.7 & & 5.505 \\
\hline & Firm size & 20. & & 1.860 \\
\hline & Tenure & 9.6 & & 9.590 \\
\hline & Age 1 & 56. & & 7.979 \\
\hline & Number of observations & 122 & & \\
\hline Good & Discretionary accruals & -0.6 & & 5.452 \\
\hline & Leverage & 0.7 & & 1.625 \\
\hline & Firm size & 20. & & 1.905 \\
\hline & Tenure & 9.3 & & 8.564 \\
\hline & Age 1 & 56. & & 8.182 \\
\hline & Number of observations & $14 \varepsilon$ & & \\
\hline Total & Discretionary accruals & -0.2 & & 4.101 \\
\hline & Leverage & 0.7 & & 3.886 \\
\hline & Firm size & 20. & & 1.885 \\
\hline & Tenure & 9.4 & & 9.041 \\
\hline & Age 1 & 56. & & 8.090 \\
\hline Panel B & & & & \\
\hline & Discriminating function & F test & & lity in means \\
\hline Discretionary accruals & 0.917 & 27.614 & & \\
\hline Leverage & -0.019 & 0.001 & 1.1 & \\
\hline Firm size & -0.349 & 4.686 & & \\
\hline Tenure & -0.009 & 0.950 & 1.5 & \\
\hline Age 1 & 0.115 & 0.522 & 1.2 & \\
\hline
\end{tabular}

Case of companies with current good performance and with current poor performance: Our discriminating analysis is conducted according to future good performance and future bad performance to show if the earning management and job security differ between the two groups.

Table 8: Discriminating analysis results according future performance

\begin{tabular}{llll}
\hline Panel A & & & \\
State of the performance & & mean & Std. dev. \\
\hline Poor & Discretionary accruals & 0.039 & 0.868 \\
& Leverage & 0.709 & 3.953 \\
& Firm size & 20.822 & 1.851 \\
& Tenure & 9.658 & 9.608 \\
& Age 1 & 56.480 & 8.126 \\
& Number of observations & 1252 & \\
Good & Discretionary accruals & -0.591 & 5.517 \\
& Leverage & 0.848 & 3.828 \\
& Firm size & 20.945 & 1.913 \\
& Tenure & 9.283 & 8.523 \\
& Age 1 & 56.384 & 8.061 \\
Panel B & Number of observations & 1458 & \\
& & & \\
Discretionary accruals & Discriminating function & F test & t-stat for equality in \\
Leverage & & & means \\
Firm size & 0.883 & 16.061 & 29.332 \\
Tenure & -0.238 & 0.852 & -6.169 \\
Age 1 & -0.329 & 2.853 & -23.444 \\
\hline
\end{tabular}


When looking at the means and the standard deviations in panel A and by conducting the same test of equality in means as in previous subsection. The results show that the variables: discretionary accruals, advantage, firm size and tenure can be used to discriminate between both groups. The result of the F-test reported in panel B of table 8 shows that only the discretionary accruals and the firm size have significant coefficients, which mean that only these two variables have a significant power to discriminate between the two groups. This result confirms those of Wilcoxon test. In the other hand, the difference in means for the job security variable is not significant when looking to the F statistic and significant if we consider the t-stat of equality in means. Indeed the average of the tenure in both groups is almost the same (approaches 10 years). This value is explained by the effect of the CEO's entrenchment.

\section{Results of the multivariate model}

Check of the multicolinearity: To test for multicolinearity between the independent variables we use the Pearson correlation coefficients. Empirical results of the correlation coefficients are reported in table 9 below. This table shows that all coefficients are smaller than 0.8 accepts between current and future performance. The Vifcolin test confirms the absence of multicolinearity between variables. All correlation coefficients are lower than $10 \%$, and statistics test cannot reject the null hypothesis. In the following subsection, we adjust our estimation to take into account the presence of multicolinearity.

Table 9: Pearson correlations and Vifcolin statistic results

\begin{tabular}{lllllllll}
\hline & Current Perf & Future Perf & Tenure & Age1 & Age2 & Type.dep & Lev & size \\
\hline Current Perf & 1 & & & & & & & \\
Future Perf & 0.958 & 1 & & & & & & \\
Tenure & -0.015 & -0.023 & 1 & & & & & \\
Age1 & -0.001 & -0.002 & 0.546 & 1 & & & \\
Age2 & -0.005 & -0.006 & 0.516 & 0.763 & 1 & & & \\
Type.dep & -0.16 & -0.165 & 0.009 & -0.089 & -0.099 & 1 & & \\
Lev & 0.041 & 0.034 & -0.031 & -0.071 & -0.037 & -0.010 & 1 \\
Size & 0.025 & 0.029 & -0.254 & -0.036 & -0.092 & -0.056 & -0.082 & 1 \\
Vifcolin & 15.09 & 21.72 & 1.608 & 2.694 & 2.524 & 1.056 & 1.036 & 1.097 \\
\hline
\end{tabular}

Results of the estimation of the model: The results of the regression using SAS software are summarized in table 10 below.

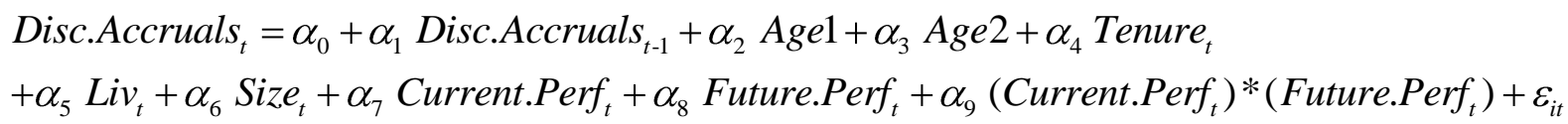
Table 10: Multivariate regressions results of Discretionary accruals on performance and control variables

\begin{tabular}{lll}
\hline & Discretional accruals & \\
\hline Independents Variables & Coefficient & t-statistic \\
\hline Intercept & -0.2709 & -2.80 \\
Disc. Accruals(t-1) & 0.0387 & 13.65 \\
Age1 & 0.0007 & 0.57 \\
Age2 & 0.0014 & 0.09 \\
Tenure & -0.0013 & -1.55 \\
Lev & 0.0156 & 0.84 \\
Size & 0.0088 & 4.62 \\
Current perf & -0.0038 & -21.36 \\
Future Perf & 0.7244 & 16.86 \\
(Current perf)* (Future Perf) & -0.0923 & -12.68 \\
\hline
\end{tabular}

The discretionary accruals of the previous year have a positive significant coefficient. This result indicates that there is an earning smoothing influenced by previous manipulations. In addition, empirical results show that magnitude of CEOs accruals manipulations is a positive function of the size and advantage variables. Moreover, the current and future performance as well as their product is significant at a level of $1 \%$ level. The current performance has a negative coefficient and the future performance has a positive coefficient. This implies that the current performance varies in the inverse sense of that of the discretionary accruals. While the future performance varies in the same sense of the discretionary 
accruals. In other words, the increase of the discretionary accruals in the earning is associated with a bad (decline) current performance and a good (increase) future performance. On the other hand, the decrease of the discretionary accruals is associated with a current good performance and a future weak performance. The estimation shows that the variable "tenure" is statistically significant at a level of $10 \%$ and it has a negative coefficient. This coefficient shows that the tenure varies in the opposite sense of that of the accruals. In a sense an increase of accruals is accompanied with a decrease of the tenure, by consequences the job security of the CEOs is affected. To avoid this situation, CEOs decrease the accruals, which will come along with a current good performance and a future bad performance. They will leave them in reserve to the detriment of current period to have the longest possible tenure. In summary, our results show that CEOs engage in earnings decreasing accruals, so they shift current earnings to future periods when current earnings is high and future earnings is low to lengthen their tenure. This confirms specially the descriptive analysis results and our second hypothesis.

\section{Discussion and Conclusion}

Fudenberg and Tirole (1995) analytically show that income smoothing can arise in equilibrium if managers are concerned about job security. DeFond and Park (1997) proves that managers smooth income according to both current and future performance, which is consistent with the predictions of the Fudenberg and Tirole (1995) model. However, their results suffer from two limitations. First, DeFond and Park (1997) do not directly examine the relation between job security and income smoothing. Second, recent studies doubt about the validity of the inferences used in DeFond and Park (1997) because of their reliance on the backing out method of estimating discretionary accruals from earnings to measure current pre-managed earnings performance. This work presents contributions to the literature of the income smoothing and the job security. Indeed, it showed that the income smoothing is an effective instrument for the CEOs to lengthen their tenure. Our results prove that CEOs engage in earnings decreasing accruals, so they shift current earnings to future periods when current earnings is high and future earnings is low to lengthen their tenure. However, our study has some deficiencies, indeed, although the modified Jones model (Dechow et al, 1995) is the most used and the most successful model in the literature, other model such as that of Dechow et al. (2003) can be used to estimate accruals. In addition, future performance can be measured using analyst's forecasts. However, the unavailability of the data prevented us from realizing such analysis. Other ways of researches that can extend this study is to introduce CEO compensation as a factor to test for job security. This can be done by examining if the CEO smoothes income to guarantee their good compensation.

\section{References}

Ahmed, A., Lobo, G. \& Zhou, J. (2001).Job security and income smoothing: An empirical test of the Model. Paper prepared for presentation at the annual meetings of American Accounting Association and the CAAA annual conference.

Boyer, M. M. \& Molina, H. O. (2006). Career concerns of top executives, managerial ownership and CEO succession. Sauder School of Business working paper.

Brickley, J., Coles, J. \& Linck, J. (1999).What happens to CEO after they retire? New evidence on career concerns. Horizon problem and CEO incentives. Working paper. University of Rochester. Simmon School of Business. Working paper FR98-10.

Chen, X. \& Cheng, Q. (2002). Abnormal accruals based anomaly and managers motivations to record abnormal accruals. Working paper. Sauder School of business.

De-Angelo, L. (1988). Managerial competition. Information costs and corporate governance. Journal of Accounting and Economic, l (10), 3-36.

Dechow, P. \& Sloan. R. (1991). Executive incentives and the horizon problem. Journal of Accounting and Economic, 14, 51-89.

Dechow, P., Sloan, R. \& Sweeney, A. P. (1995). Detecting earning management. The Accounting Review, 70, 193-225.

Dechow, P., Richardson, S. \&Tuna A. (2003). Why are earnings kinky? An examination of the earnings management explanation. Review of Accounting Studies, 8(2-3), 355-384.

Defond, M. L. \& Park. C. W. (1997). Smoothing income in anticipation of future earning. Journal of Accounting and Economic, 1(23), 115-139.

Demers, E. \& Wang. C. (2010). The Impact of CEO Career Concerns on Accruals Based and Real Earnings Management. Finance and Corporate Governance Conference 2011 Paper. 
Elliot, J. \& Shaw, W. (1988). Write offs as accounting procedures to manage perceptions. Journal of Accounting Research, 26, 91-119.

Fama, E .F. (1980). Agency problems and the theory of the firm. Journal of Political Economy, 88, 2883087.

Fudenberg, D. \& Tirole, J. (1995). A theory of income and dividend smoothing based on incumbency rents. Journal of Political Economy, 103, 75-93.

Gibbons, R. \& Murphy, K. J. (1990). Relative performance evaluations for chief executive office. Industrial and Labor Relations Review, 43(3), 30-51.

Gaver, J., Gaver, K. M. \& Austin, J. R. (1995). Additional evidence on bonus plans and income management. Journal of Accounting and Economic, 19, 3-28.

Godfrey, J., Mather, P. \& Ramsay, A. (2001).Earning and impression management in financial reports: The case of CEO change. ABACUS, 39, 95-123.

Goyal, W. K. \& Park, C. W. (2001). Board leadership structure and CEO turnover. Journal of Corporate Finance, 8, 49-66.

Guay, W. R., Kothari, S. P. \& Watts, R. L. (1996). A market-based evaluation of discretionary accrual models. Journal of Accounting Research, 34, 83-105.

Guenther, N., Gegenfurtner, B., Kaserer, C. \& Achleitner, A. K. (2009). International Financial Reporting Standards and Earnings Quality: The Myth of Voluntary vs. Mandatory Adoption. Working Paper. Technische Universität München.

Hazarika. S., Karpoff, J. M. \&Nahata. R. (2011). Internal corporate governance. CEO turnover. In addition, earnings management. Working papers. University of New York.

Healy, P. M. \& Wahlen, J. M. (1998). A review of the earning management literature and its implication for standard setting. Journal of Accounting, 4, 1-34.

Jones, J. (1991). Earnings management during import relief investigations. Journal of Accounting Research, 29, 193-228.

Koch, T. W. \& Wall, L. D. (2000). The use of accruals to manage reported earning: Theory and evidence. Federal Reserve Bank of Atlanta working paper 2000-23.

Kothari, S. P., Leone, A. J. \& Wasley, C. E. (2005). Performance matched discretionary accruals, Simon School of Business Working Paper No. FR 01-04; MIT Sloan Working Paper No. 4335-01.

Lambert, R. (1984). Income smoothing as rational equilibrium behaviour. The Accounting Review, LIX, 604-618.

Lee, C. (2007). What has happened over the past 10 years to the selection of retired CEOs as board members? Indiana University. CAEPR Working paper $\mathrm{N}^{\circ} 2007.007$.

Murphy, K. \& Zimmerman, J. (1993). Financial performance surrounding C.E.0 turnover. Journal of Accounting and Economic, 16, 273-316.

Pourciau, S. (1993). Earning management and non-routine executive change. Journal of Accounting and Economic, 16, 317-336.

Paquerot, M. (1996). L'enracinement des dirigeants et ses effets. Revue Française de Gestion, NOV/DEC, 212-225.

Schipper, K. (1989).Commentry on earning management. Accounting Horizons, 3(4), 91-102.

Song, F. \& Thakor, A. V. (2006). Information Control. Career Concerns. In addition, Corporate Governance. Journal of Finance, Forthcoming, 61(4), 1845-96.

Weishback, M. (1988). Outside directors and CEO turnover. Journal of Financial Economic, 20, 431-460.

Ye, J. (2007). Accounting accruals and tests of earnings management, Document de travail, Social, Science Research Network.

Zhang, W. (2009). CEO Tenure and Earnings Quality. Working paper, School of Management, University of Texas at Dallas. 


\section{Appendix}

Table 4(a): Mann-Whitney Test Ranks

\begin{tabular}{lllll}
\hline & & \multicolumn{3}{c}{ Current Performance } \\
& & N & Mean rank & Sum of rank \\
\hline Discretionary accruals & Poor & 1221 & 1920.13 & 2344474.00 \\
& Good & 1489 & 892.50 & 1328931.00 \\
& Total & 2710 & & \\
\hline
\end{tabular}

Table 4(b): The results of the Mann-Whitney (U) and Wilcox on (W) tests Discretionary accruals**

\begin{tabular}{ll}
\hline Mann-Whitney U & 219626.000 \\
Wilcox on W & 1328931.000 \\
Z & -34.018 \\
$P$-value Asymp. Sig. (2-tailed) & 0.000 \\
\hline ** Grouping Variable: Current performance &
\end{tabular}

Table 5(a): Mann-Whitney Test Ranks

\begin{tabular}{lllll}
\hline & Performance future & N & Mean rank & Sum of rank \\
\hline \multirow{3}{*}{ Discretionary accruals } & Poor & 1252 & 1515.48 & 1894354.00 \\
& Good & 1458 & 1216.48 & 1773632.00 \\
& Total & 2710 & & \\
\hline
\end{tabular}

Table 5(b): The results of the Mann-Whitney (U) and Wilcox on (W) tests

\begin{tabular}{ll}
\hline & Discretionary accruals $^{* *}$ \\
\hline Mann-Whitney U & 710021.000 \\
Wilcox on W & 1773632.000 \\
Z & -9.921 \\
$P$-value Asymp. Sig. (2-tailed) & 0.000 \\
\hline ** Grouping Variable: Future performance &
\end{tabular}

